\title{
RAND Experts Available to Discuss Possible Security Agreement in Afghanistan
}

RAND experts are available to discuss a possible security agreement between the United States and Afghanistan that would permit U.S. forces to remain in Afghanistan past 2014. President Hamid Karzai and more than 2,000 other Afghan officials are considering the agreement this week during a "loya jirga," a national forum of Afghan leaders to review national issues.

Among the topics RAND experts can address:

- How important is the security agreement to U.S. interests?

- What role does the loya jirga play in a final agreement decision?

- What type of U.S. forces would remain in Afghanistan beyond 2014? Why are they needed?

- One potential obstacle to a security agreement is the tactic of using home raids by U.S. forces to capture extremists. Are such raids useful and important?

- How would an agreement change the political dynamics in Kabul ahead of their next presidential election in April?

Seth Jones is associate director of the RAND International Security and Defense Policy Center, and author of "Hunting in the Shadows: The Pursuit of al Qa'ida after 9/11." He recently testified before Congress on "After the Withdrawal: A Way Forward in Afghanistan and Pakistan."

Arturo Munoz is a senior political scientist and former operations officer in the CIA Counterterrorism Center. A former advisor to the Marines in Afghanistan, he is the author of "Assessing Military Information Operations in Afghanistan, 2001-2010."

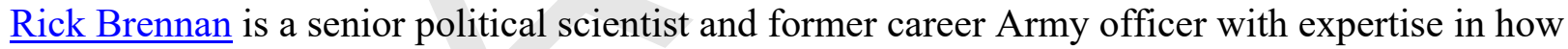
lessons from the Iraq transition can be applied to Afghanistan. He is co-author of the justpublished "Ending the U.S. War in Iraq: The Final Transition, Operational Maneuver, and Disestablishment of United States Forces-Iraq."

Ben Connable is a senior international policy analyst and former head of the Marine Corps cultural intelligence program in Iraq. He is author of, "How Insurgencies End."

Paul Miller is a political scientist specializing in state building, stability operations and peacekeeping. He is the former director for Afghanistan and Pakistan on the National Security Council staff (2007-2009) and author of "The US and Afghanistan After 2014."

Dave Baiocchi is a senior engineer with expertise assessing the demands placed upon the Army by deployments to Iraq and Afghanistan. He is the author of "Measuring Army Deployments to Iraq and Afghanistan."

\section{Interviews}


To arrange an interview, contact the RAND Office of Media Relations:

(703) 414-4795 or

(310) 451-6913, or

send an email to media@,rand.org.

\section{About the RAND Corporation}

The RAND Corporation is a research organization that develops solutions to public policy challenges to help make communities throughout the world safer and more secure, healthier and more prosperous. 